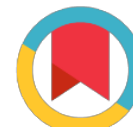

Check for updates

*For correspondence:

tathanhvan@hmu.edu.vn

Competing interests: The authors declare that no competing interests exist.

Received: 2017-08-23

Accepted: 2017-09-01

Published: 2017-09-05

Copyright The Author(s) 2017. This article is published with open access by BioMedPress (BMP).

This article is distributed under the terms of the Creative Commons Attribution License (CC-BY 4.0) which permits any use, distribution, and reproduction in any medium, provided the original author(s) and the source are credited.

\section{Immune-cell base for cancer therapy}

Van Thanh Ta, Thinh Huy Tran, Binh Thanh Nguyen, Linh Quy Nguyen, Hoai Quy Nguyen, Khanh Van Tran

Hanoi Medicine University, Hanoi, Vietnam

\section{Abstract}

The development of immune cell-based approaches for treatment of cancer has been actively investigated for many years. One strategy that has been demonstrated as an effective method for cancer treatment is adoptive $T$ cell therapy. The principle of this method is using Cytotoxic $T$ lymphocytes (CTL), a crucial component of the adaptive immune system that aids in the control of intracellular pathogens. Effector CTL have the capacity to promote the apoptotic death of specifically targeted cells, using a combination of granule (perforin/granzyme)-and receptor (Fas/tumor necrosis factor)-mediated mechanisms. CTL recognize specific antigen on target cells using an unique T-cell receptor (TCR) when they are presented by class I major histocompatibility (MHC) molecules. In this study, we demonstrated that $\mathrm{T}$ lymphocytes were activated and dramatically expanded by stimulation with anti-CD3/CD28 antibodies and culture in the present of IL-2, IL-15 and IL-21 cytokines. These $T$ cells exhibited a predominantly activated phenotype as manifested by an increase in the percentage of cells expressing CD8 and generation of various cytokines such as IL-2, INFY and TNFa. These findings indicate that stimulation by anti- CD3/CD28 generated effector CTL in adoptive T-cell therapy for cancer.

\section{Keywords}

Immune cell, cancer therapy, Cytotoxic T lymphocytes

\title{
References
}

Biomed Res Ther 2017, 4(S)

DOI 10.15419/bmrat.v4iS.217 